\title{
B7-H3/CD276: An Emerging Cancer Immunotherapy
}

\begin{abstract}
Wu-Tong Zhou ${ }^{1}$ and Wei-Lin Jin ${ }^{1,2 *}$
1 Institute of Nano Biomedicine and Engineering, Shanghai Engineering Center for Intelligent Diagnosis and Treatment Instrument, Department of Instrument Science and Engineering, Key Laboratory for Thin Film and Microfabrication Technology of Ministry of Education, School of Electronic Information and Electronic Engineering, Shanghai Jiao Tong University, Shanghai, China, ${ }^{2}$ Institute of Cancer Neuroscience, Medical Frontier Innovation Research Center, The First Hospital of Lanzhou University, The First Clinical Medical College of Lanzhou University, Lanzhou, China
\end{abstract}

Immunotherapy aiming at suppressing tumor development by relying on modifying or strengthening the immune system prevails among cancer treatments and points out a new direction for cancer therapy. B7 homolog 3 protein (B7-H3, also known as CD276), a newly identified immunoregulatory protein member of the B7 family, is an attractive and promising target for cancer immunotherapy because it is overexpressed in tumor tissues while showing limited expression in normal tissues and participating in tumor microenvironment (TME) shaping and development. Thus far, numerous B7-H3-based immunotherapy strategies have demonstrated potent antitumor activity and acceptable safety profiles in preclinical models. Herein, we present the expression and biological function of B7-H3 in distinct cancer and normal cells, as well as B7-H3-mediated signal pathways in cancer cells and B7-H3-based tumor immunotherapy strategies. This review provides a comprehensive overview that encompasses B7-H3's role in TME to its potential as a target in cancer immunotherapy.

Keywords: B7-H3/CD276, immune checkpoint, tumor microenvironment, tumor immunology, cancer immunotherapy

\section{INTRODUCTION}

Immunotherapy that results in remarkable and durable responses across many different tumor types in patients by promoting antitumor immune responses has revolutionized the treatment of cancer over the past decade (1). Cancer immunotherapies based on immune evasion mechanisms, which are represented by B7-H1/PD-1 pathway targeting (anti-PD therapy), have achieved higher objective response rates in patients with considerably fewer immune-related adverse events than immune enhancement, indicating that normalization cancer immunotherapy has come of age with

\footnotetext{
Abbreviations: PD-1, Programmed cell death protein 1; TME, Tumor microenvironment; B7-H3, B7 homolog 3 protein; DCs, Dendritic cells; MMP, Matrix metallopeptidase; TLT-2, TREM-like transcript 2; CRC, Colorectal cancer; IHC, Immunohistochemistry; NSCLC, Non-small cell lung cancer; MCC, Merkel cell carcinoma; GM-CSF, Granulocytemacrophage colony stimulating Factor; CSC, Cancer stem cells; EMT, Endothelial-to-mesenchymal; MKP, MAP kinase phosphatase; Cyt.c, Cytochrome c; NF-кB, Nuclear factor kappa B; CICs, Cancer initiating cells; JK , Janus kinase; STAT, Signal transducer and activator of transcription; NK, Natural killer cells; ADCC, Antibody-dependent cell-mediated cytotoxicity, ADCs, Antibody-drug conjugates; DCs, Dendritic cells; BsAbs, Bispecific antibodies; TriKEs, Trispecific Killer Engagers, CAR, Chimeric antigen receptor; CNS, Central nervous system.
} 
the strenuous efforts expended to enhance clinical efficacy. The concept of immune normalization emphasizes the importance of specifically correcting immune deficiencies to restore natural antitumor immune capacity (2). The $\mathrm{B} 7$ superfamily provides the second signal of the T-cell activation process, which is necessary to ensure an appropriate immune response; several members of the $\mathrm{B} 7$ superfamily, which is represented by B7-H1/PD-1, have been implicated in immune deficiency in the tumor microenvironment (TME) (3-5). The B7 superfamily can be divided into three groups in accordance with the signals that they transduct during T-cell activation: I) costimulatory, II) coinhibitory, and III) costimulatory/inhibitory (6).

B7 homolog 3 protein (B7-H3), also known as CD276, is an immune checkpoint molecule and a costimulatory/coinhibitory immunoregulatory protein that plays a dual role in the immune system (7). It was first cloned in 2001 from a cDNA library that was derived from human dendritic cells (DCs) (8). The human B7-H3 gene is located on chromosome 15, and the murine B7$\mathrm{H} 3$ gene has been mapped to chromosome 9 (3). The human B7$\mathrm{H} 3$ protein exists either as a transmembrane or soluble isoform. Transmembrane $\mathrm{B} 7-\mathrm{H} 3$ is a type I transmembrane protein that contains 316 amino acids and has a molecular weight of $\sim 45-66$ $\mathrm{kDa}(8,9)$. It is composed of an extracellular domain, a transmembrane domain, and a short intracellular domain. The extracellular domain in murine $\mathrm{B} 7-\mathrm{H} 3$ (2IgB7-H3, B7-H3 VC) is composed of a single pair of immunoglobulin variable domain and constant domain and human B7-H3 (4IgB7-H3, B7-H3 VCVC) is composed of two pairs due to exon duplication (10, 11). Soluble B7-H3 (sB7-H3), which is cleaved from the surface by a matrix metallopeptidase (MMP) or produced through the alternative splicing of the intron, has also been detected in human sera $(12,13)$. The B7-H3 protein has also been found in the secretome, including exosomes and other extracellular vesicles (14). Asuthkar et al. found that $\mathrm{B} 7-\mathrm{H} 3$ induces greater exosome secretion and stimulates increased exosome size in D283 medulloblastoma cells (15).

TREM-like transcript 2 (TLT-2) has been identified as a potential receptor of $\mathrm{B} 7-\mathrm{H} 3$ (16). However, TLT-2 may not be the only receptor of $\mathrm{B} 7-\mathrm{H} 3$ considering that $\mathrm{B} 7-\mathrm{H} 3$ has many contradictory roles. In contrast to other immune checkpoints, B7$\mathrm{H} 3$ not only influences innate and adaptive immunity but also regulates the aggressiveness of cancer cells through various nonimmunological pathways (17). Various anti-B7-H3 approaches have been studied in preclinical and clinical trials and have demonstrated their feasibility for clinical application (18).

\section{B7-H3 IS HIGHLY EXPRESSED IN DIFFERENT TYPES OF HUMAN CANCERS}

In most normal human tissues, B7-H3 mRNA is expressed widely, whereas the $\mathrm{B} 7-\mathrm{H} 3$ protein is relatively rarely present; the difference between the mRNA and protein expression patterns of B7-H3 suggests that B7-H3 has a tight posttranscriptional regulation mechanism (19). Evidence suggests that miR-124 may cause translational repression by playing a tumor suppressor role and targeting the 3'-UTR of B7-H3 (20). Furthermore, miR-29 overexpression can inhibit B7-H3 expression levels, which play a crucial role in promoting medulloblastoma angiogenesis (21). Besides, $\mathrm{B} 7-\mathrm{H} 3$ expression is negatively regulated by miR-128 in colorectal cancer (CRC) (22).

We obtained datasets on the differential expression of B7-H3 in distinct cancers from the Oncomine online database (Figure 1) and B7-H3 transcripts across all tumor samples and paired normal tissues from the Gene Expression Profiling Interactive Analysis (GEPIA) online database (Figure 2). We could find that CD 276 is highly expressed in both mRNA and protein level in tumor cells.

B7-H3 has been extensively studied in various cancers, including but not limited to breast cancer, lung cancer, ovarian cancer, brain tumor, gastric cancer, and squamous cell carcinoma (Table 1). Its presence has been correlated with worsened prognosis, poor survival, and recurrence rate. B7H3's capability to confer enhanced invasive and migratory properties has been further studied by using in vitro cancer models and is highlighted below.

\section{B7-H3 in Breast Cancers}

Breast cancer is the most frequently diagnosed cancer in women worldwide and the second leading cause of cancer deaths among women $(31,32)$. A study on American Joint Committee on Cancer stages I to III primary breast cancers and normal breast specimens found that $\mathrm{B} 7-\mathrm{H} 3$ was expressed in 32 out of 82 primary breast tumors and compared with normal breast tissue, B7-H3 expression in primary tumors had a significant correlation with increased tumor size and lymph vascular invasion (33). By utilizing immunohistochemistry (IHC), Yu et al. discovered that the positive rate of $\mathrm{B} 7-\mathrm{H} 3$ was $56.8 \%$ (42/ $74)$ in 74 specimens of breast cancer tissues and was higher than $43.2 \%(32 / 74)$ in 74 specimens of adjacent tissues (23).

\section{B7-H3 in Lung Cancers}

B7-H3 has been studied in non-small cell lung cancer (NSCLC). NSCLC is one of the cancers with the highest morbidity and mortality worldwide (34). Studies have shown that B7-H3 molecules are closely related to the invasion, metastasis, proliferation, and prognosis of NSCLC tumors (35). Yonesaka et al. evaluated B7-H3 expression levels in NSCLC tumors by using IHC and found that $74 \%$ of the tumor samples expressed B7-H3 with a staining pattern of $1+, 2+$, or $3+(24)$. Moreover, Wang et al. found that CD276 silencing inhibited cell invasion and migration by reducing integrin-associated protein expression (35). These studies indicated that in NSCLC, the presence of $\mathrm{B} 7-\mathrm{H} 3$ contributes to the capability of malignant neoplasms to progress and metastasize.

\section{B7-H3 in Ovarian Cancers}

B7-H3 has also attracted interest in the field of ovarian cancer research. By applying IHC, Zang et al. found that B7-H3 expression was present in 96 out of 103 (93\%) ovarian tumors (25). Notably, in the ovarian TME, stromal cells express B7-H3 at higher levels than tumor cells (36). Cai et al. assessed the expression of $\mathrm{B} 7$ checkpoint molecules in $\mathrm{OvCa}$ and found that 
Disease Summary for CD276
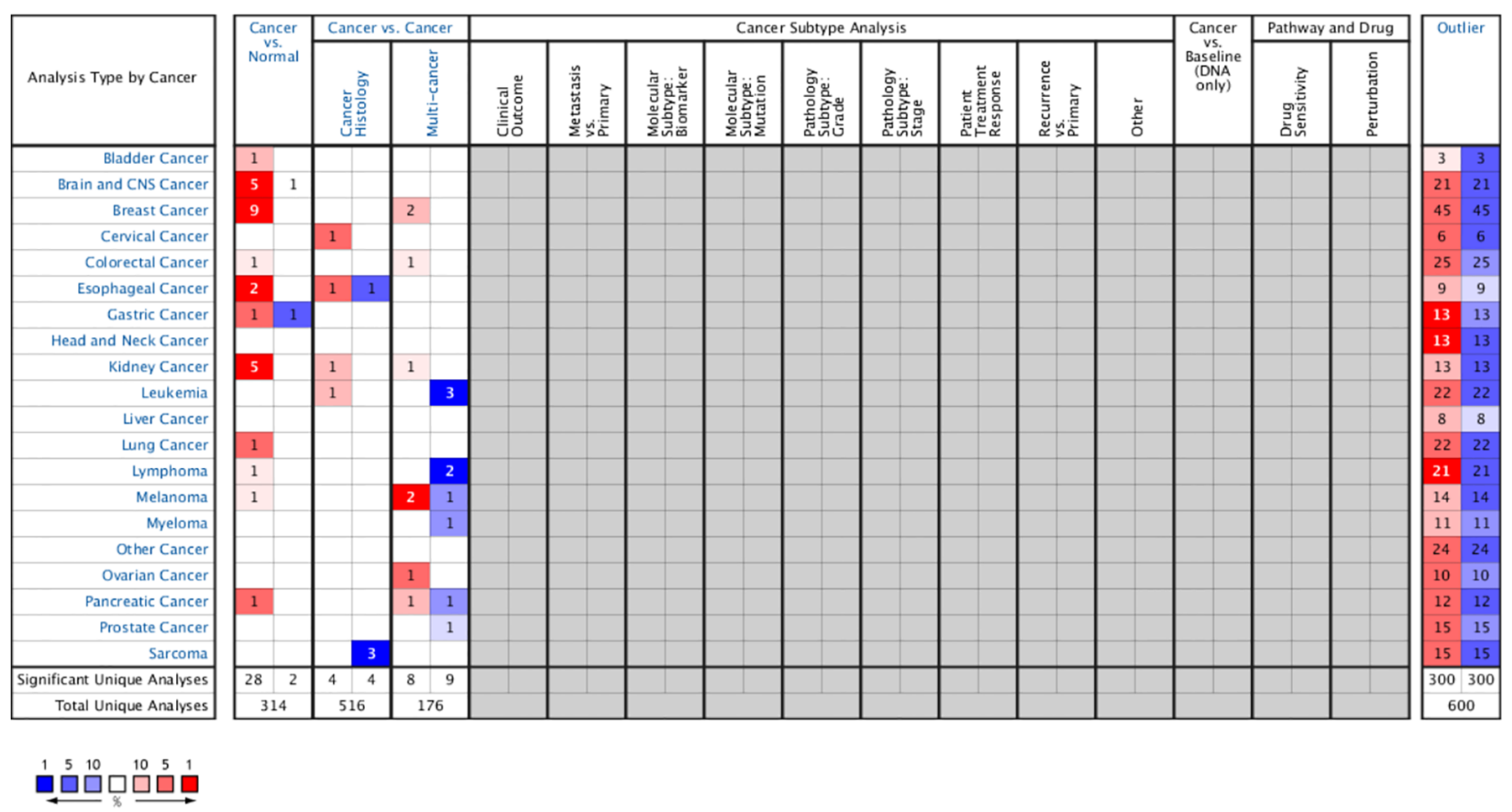

FIGURE 1 | B7-H3 differential expression datasets in distinct cancers. P-value equals 0.05 , fold change equals 2, red indicates high expression, and the darker the color, the higher the expression, blue indicates vice versa (only comparisons within the same row). Gray and blank means no data. Cell color is determined by the best gene rank percentile for the analyses within the cell (Note: an analysis may be counted in more than one cancer type). www.oncomine.org.

B7-H3, but not PD-L1, was highly expressed and that the high expression of $\mathrm{B} 7-\mathrm{H} 3$ was associated with dysfunction in tumorinfiltrating $\mathrm{T}$ cells (37).

\section{B7-H3 in Brain Cancers}

Multiple studies have shown that $\mathrm{B} 7-\mathrm{H} 3$ is present in a range of brain cancers. Different types of gliomas have different B7-H3 expression levels. Weak B7-H3 expression was found in oligodendroglioma and choroid plexus papilloma specimens. B7-H3 was expressed at moderate-to-high levels in medulloblastoma, ependymocytoma, glioblastoma, anaplastic astrocytoma, glioblastoma multiforme, and diffuse intrinsic pontine glioma $(3,38)$. The differential expression of B7-H3 in different types of gliomas requires further study. A previous study showed that all 16/21 meningioma specimens presented high B7$\mathrm{H} 3$ expression with strong membrane staining in almost $100 \%$ of tumor cells and that $\mathrm{B} 7-\mathrm{H} 3$ expression in the five remaining meningioma tissues was moderate to high (26). B7-H3 expression was detected in $75 \%-90 \%$ of the tumor tissues in six out of eight cases, and extremely low levels of B7-H3 were detected in normal brain tissues (27). Wang et al. revealed that $2 \operatorname{IgB} 7-\mathrm{H} 3$, but not 4IgB7-H3, was specifically expressed in gliomas; they also demonstrated for the first time that $2 \operatorname{IgB} 7-\mathrm{H} 3$ was a valuable biomarker for the diagnosis of glioma (39). Proctor et al. found that $\mathrm{B} 7-\mathrm{H} 3$ was the most prevalent and abundant inhibitory immune checkpoint protein quantified in meningioma (26).

\section{B7-H3 in Other Cancers}

$\mathrm{Li}$ et al. demonstrated that $\mathrm{B} 7-\mathrm{H} 3$ promoted gastric cancer cell migration and invasion and that its upregulation enhanced tumor infiltration depth (28). Wang et al. found that B7-H3 was involved in the progression of esophageal squamous cell carcinoma and the tumor escape of immunosurveillance (29). Varki et al. discovered that in patients who were positive for HIV and had cutaneous squamous cell carcinoma, the significantly higher B7-H3 expression levels of tumor cells in immunocompetent patients than in immunosuppressed individuals was largely driven by reduced B7$\mathrm{H} 3$ expression (30). Besides, Tetzlaff et al. found that B7-H3 expression in Merkel cell carcinoma (MCC)-associated endothelial cells correlates with locally aggressive primary tumor features and increased vascular density (40).

\section{B7-H3 in Normal Cells}

Human B7-H3 protein is not expressed constitutively on monocytes, B, T, or NK cells but can be induced on these cell types $(8,11)$. Phorbol myristate acetate plus ionomycin can induce the surface expression of $\mathrm{B} 7-\mathrm{H} 3$ on $\mathrm{T}, \mathrm{B}$, and $\mathrm{NK}$ cells (11). Anti-IgM also promotes $\mathrm{B} 7-\mathrm{H} 3$ expression on murine $\mathrm{B}$ cells. Anti-CD40 can induce B7-H3 expression on murine macrophages and B cells. LPS stimulates B7-H3 protein expression on murine DC and macrophages. In murine DCs, B7-H3 mRNA expression is stimulated by IFN- $\gamma$ but is suppressed by IL-4 (41). B7-H3 expression can be induced by 


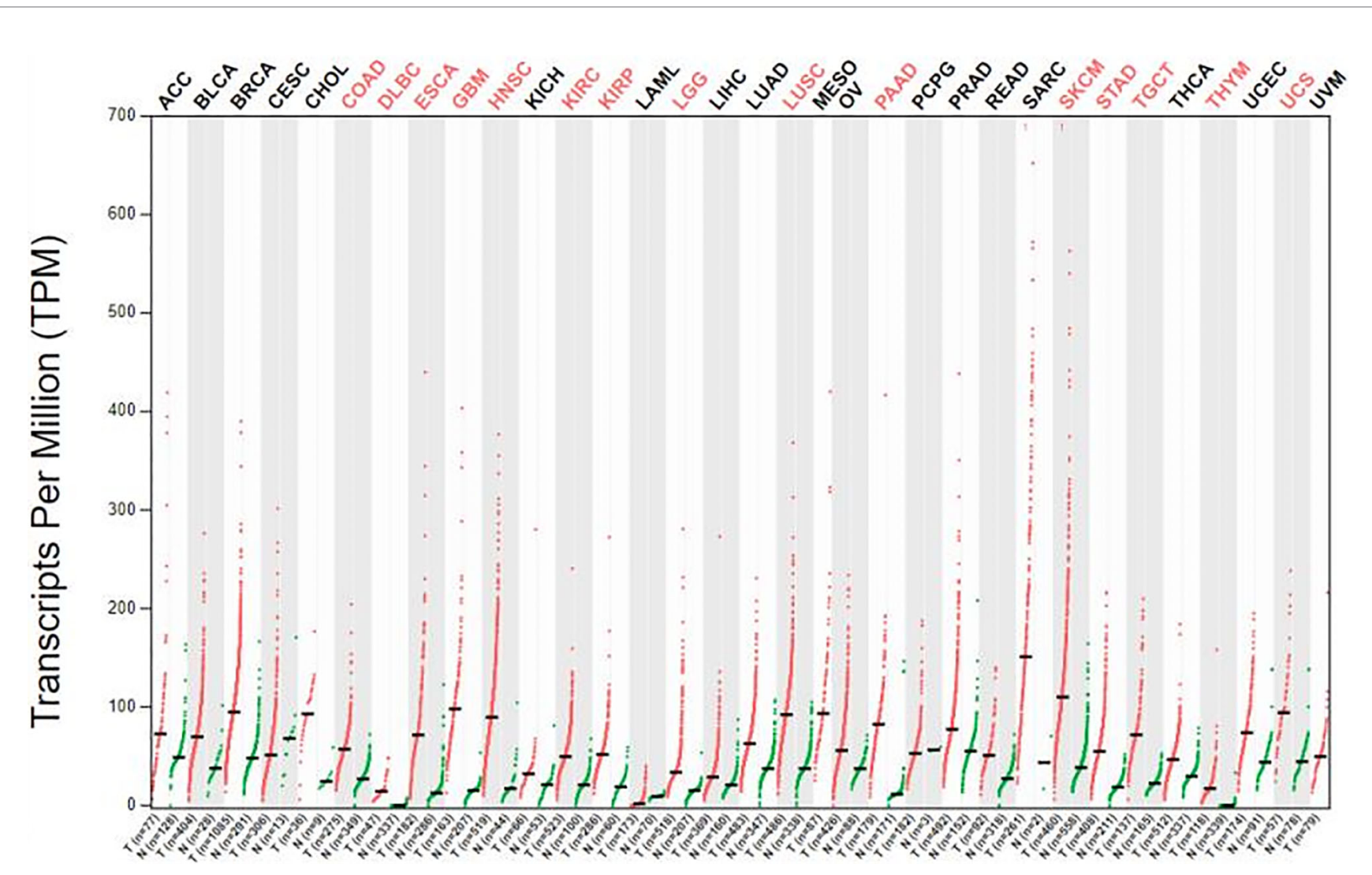

FIGURE 2 | The gene expression profile across all tumor samples and paired normal tissue (dot plot). Labels upward the figure show different types of tumor marked different color, red show statistic data have significant difference, black show statistic data have no significant difference; The $\mathrm{X}$ axis is the number of tumor samples $(\mathrm{T})$ in red and normal samples $(\mathrm{N})$ in green for each tumor. The $\mathrm{Y}$ axis is transcripts per million (TPM). gepia.cancer-pku.cn

TABLE 1 | Expression and diverse roles of B7-H3 in multiple types of human cancers.

\begin{tabular}{|c|c|c|c|c|c|}
\hline Cancer type & $\begin{array}{c}\text { Case } \\
\text { number }\end{array}$ & Positive rate $(\%)$ & Cell category & Function & Reference \\
\hline \multirow[t]{2}{*}{ Breast cancer } & 74 & $56.8(42 / 74)$ & Cancer tissue & $\mathrm{B} 7-\mathrm{H} 3$ participated in the occurrence and metastasis of breast cancer & (23) \\
\hline & 74 & $43.2(32 / 74)$ & Adjacent tissue & & \\
\hline $\begin{array}{l}\text { Non-small cell lung } \\
\text { cancer }\end{array}$ & 82 & 74 & Tumor samples & B7-H3 impaired anti-PD-1 therapy in NSCLC & $(24)$ \\
\hline Ovarian cancer & 103 & 93 & Tumor samples & B7-H3 downregulated T cell mediated antitumor immunity & $(25)$ \\
\hline \multirow[t]{2}{*}{ Meningioma } & 21 & 76.2 & Tumor cells & $\begin{array}{l}\text { B7-H3 expression was elevated in patients with gene mutations related to the } \\
\qquad \mathrm{PI} 3 \mathrm{~K} / \mathrm{AKT} / \mathrm{mTOR} \text { pathway }\end{array}$ & (26) \\
\hline & 8 & 75 & Tumor tissues & $\mathrm{B} 7-\mathrm{H} 3$ protein might play important roles in meningioma immune responses & $(27)$ \\
\hline Gastric cancer & 120 & 69.2 & Cancer tissues & B7-H3 silencing downregulates CXCR4 & $(28)$ \\
\hline $\begin{array}{l}\text { Esophageal } \\
\text { squamous cell } \\
\text { carcinoma }\end{array}$ & 66 & 69.7 & Cancer tissues & $\begin{array}{l}\text { Knockdown of B7-H3 on tumor cells suppressed ESCC cell migration and } \\
\text { invasion }\end{array}$ & $(29)$ \\
\hline $\begin{array}{l}\text { Cutaneous } \\
\text { squamous cell } \\
\text { carcinoma }\end{array}$ & 66 & 85 & Tumor tissues & $\begin{array}{l}\text { B7-H3 expression was the only parameter in immunocompetent individuals } \\
\text { that was significantly different from that in immunosuppressed patients }\end{array}$ & $(30)$ \\
\hline
\end{tabular}

Not all clinical studies were included in this table due to the space limitation.

the granulocyte-macrophage-colony-stimulating factor LPS on monocytes and by IFN- $\gamma$ on DCs $(8,11)$. B7-H3 also has functions in somatic cells. B7-H3 is highly expressed on osteoblasts during embryogenesis and is crucial for osteoblastic differentiation and bone mineralization (42).
B7-H3 is overexpressed in numerous tumor types. It is not expressed or expressed at low levels in either lymphoid cells or lymphocytes but exhibits increased expression when induced. These expression patterns imply that B7-H3 may play an important role in tumor development and cancer immunity. 


\section{THE SIGNALING PATHWAYS MEDIATED BY B7-H3 IN A DISTINCT MANNER}

The high expression of $\mathrm{B} 7-\mathrm{H} 3$ in tumor tissues has aroused researchers' interest in the role of $\mathrm{B} 7-\mathrm{H} 3$ in the TME. A large body of experimental evidence indicates that B7-H3 can affect the progression of tumors through immune-dependent and nonimmune pathways.

\section{Immune-Dependent Direction \\ Co-Stimulatory Role}

B7-H3 has been suggested to play conflicting molecular roles in the immune system. B7-H3 was originally identified as a costimulatory molecule. In the presence of the anti-CD3 antibody, human $\mathrm{B} 7-\mathrm{H} 3$ protein increases the proliferation of $\mathrm{CD} 4+$ and CD8+ T-cells and enhances cytotoxic T-cell activity (8). CRCbearing mouse models treated with adenoviral B7-H3 showed suppressed tumor growth and reduced secondary metastasis occurrence with significantly higher frequencies of IFN- $\gamma$ producing CD8+ $\mathrm{T}$ cells and higher IL-12 levels than the control group mice $(43,44)$.

\section{Co-Inhibitory Role}

In addition to its co-stimulatory role, B7-H3 plays a coinhibitory role in antitumor immunity. Several current studies have shown that $\mathrm{B} 7-\mathrm{H} 3$ inhibits the proliferation of $\mathrm{CD} 4+$ and CD8+ T-cells and reduces the production of IL-2 and IFN- $\gamma$ possibly through the suppression of NF- $\kappa \mathrm{B}$, the nuclear factor of activated T-cells, and activator protein-1-mediated signaling pathways $(41,45)$ (Figure 3). During T-cell activation, B7-H3 potently and consistently inhibits of $\mathrm{T}$-cell proliferation and IFN- $\gamma$, IL-13, IL-10, and IL-2 production (Figure 3). In addition to its inhibitory effect on T-cells, B7-H3 inhibits NK cell activity. 4Ig-B7-H3-transfected $\mathrm{CHO}-\mathrm{K}$ cells avoided NKcell-mediated cytotoxicity with an unclear receptor $(11,46)$. Recently, Wang et al. found that cancer stem cells (CSCs) utilize B7-H3 to evade immune surveillance during head and neck squamous cell carcinoma initiation, development, and metastasis (47). The suppressive immune microenvironment shaped by B7-H3 helps cancer avoid immune destruction (48).

\section{Non-Immune Direction}

In addition to its role in immunological pathways, B7-H3 has nonimmunological protumorigenic functions, such as the

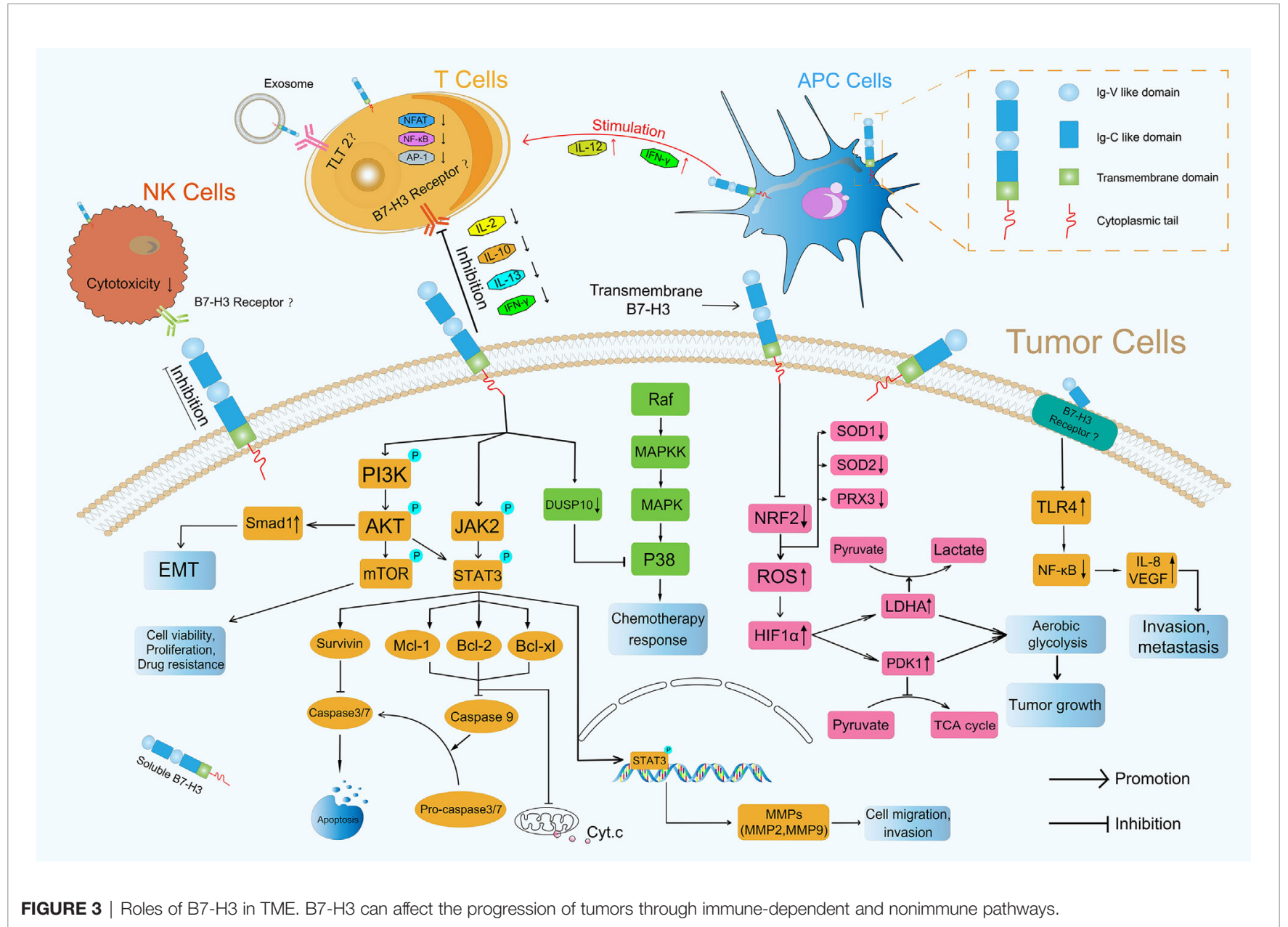


promotion of migration and invasion, antiapoptosis, cell viability, chemoresistance, and endothelial-to-mesenchymal (EMT) transition. In tumor cells, it also participates in reprogramming metabolism through vital intracellular signal transduction pathways.

\section{PISK/AKT}

Many articles have reported that the PI3K/AKT signaling pathway which is activated by phosphorylation is involved in the invasion of cancer cells (49-51) and participates directing immune cell differentiation and function (52). Li et al. found that B7-H3 overexpression promoted the migration and invasion of human bladder cancer cells and that B7-H3 knockdown suppressed the expression of MMP2 and MMP9 via the PI3K/ AKT/STAT3 signaling pathway (53) (Figure 3). Nunes-Xavier et al. used API-2 (triciribidine, an AKT inhibitor) and RAD-001 (everolimus, a mTOR inhibitor) to target the PI3K/AKT/mTOR pathway and discovered that the inhibition of cell viability and proliferation in B7-H3 knockdown tumor cells was enhanced relative to that in their counterparts (54) (Figure 3). Jiang et al. found that B7-H3 upregulated Smad1 expression via the PI3K/ AKT pathway, downregulated $\beta$-catenin and E-cadherin expression, and increased vimentin and $\mathrm{N}$-cadherin expression, indicating that $\mathrm{B} 7-\mathrm{H} 3$ promoted EMT in colorectal cancer (55) (Figure 3). The expression of MMP2, MMP9 and EMT formation can contribute to mechanical microenvironment shaping in TME (48).

\section{NF- $\kappa B$}

$\mathrm{NF}-\kappa \mathrm{B}$ transcription factors are activated as a response to a variety of signals (56). Wang et al. revealed that B7-H3 knockdown obviously reduced the phosphorylation levels of AKT, NF- $\kappa$ B, and STAT3 in HCT116 and RKO cells and that the NF- $\kappa \mathrm{B}$ pathway had a major effect on $\mathrm{B} 7-\mathrm{H} 3$-induced VEGFA expression in CRC cells (57). Xie et al. proved that sB7-H3 first upregulated TLR4 expression, then activated NF- $\kappa B$ signaling, and finally promoted IL-8 and VEGF expression and demonstrated for the first time that sB7-H3 promoted the invasion and metastasis of pancreatic carcinoma cells through the TLR4/NF- $\kappa$ B pathway (58) (Figure 3).

\section{Ras/Raf/MEK/MAPK}

MAPK pathways regulate various cellular processes through four major pathways as defined by their MAPK effector: ERK1/2, ERK5, JNKs, and p38 MAPK (59). Flem-Karlsen et al. found that the knockdown of $\mathrm{B} 7-\mathrm{H} 3$ increased the in vitro and vivo sensitivity of melanoma cells to the chemotherapeutic agents dacarbazine and cisplatin in parallel with a reduction in p38 MAPK phosphorylation; they also observed the increased expression of dual-specific MAP kinase phosphatase (MKP) DUSP10 (a MKP known to dephosphorylate and inactivate p38 MAPK) in B7-H3 knockdown cells, indicating that B7-H3mediated chemoresistance in melanoma cells is driven through a mechanism involving the DUSP10-mediated inactivation of p38 MAPK (60) (Figure 3).

\section{JAK2/STAT3}

The JAK/STAT signaling pathway is a critical controller of cellular survival and proliferation and is involved in cell antiapoptosis (61). The JAK2/STAT3 pathway activates some apoptosis suppressors, including survivin, Mcl-1, Bcl-xL, and $\mathrm{Bcl}-2$, that block caspase cascades and apoptosis initiation in tumor cells (62). The direct inhibition of effector caspases 3 and 7 by survivin results in the suppression of apoptosis (63). Mcl-1, $\mathrm{Bcl}-2$, and $\mathrm{Bcl}-\mathrm{xL}$ inhibit the release of Cytochrome $\mathrm{c}$ (Cyt.c), thus preventing Cyt.c from reaching the threshold necessary for caspase cascades (64) (Figure 3). Several studies have demonstrated that $\mathrm{B} 7-\mathrm{H} 3$ performs an antiapoptotic role in tumorigenesis via the JAK2/STAT3 pathway. Liu et al. discovered that the knockdown of $\mathrm{B} 7-\mathrm{H} 3$ abrogated the phosphorylation of STAT3 through the inactivation of JAK2 and led to the downregulation of the direct target genes of STAT3 and to the reduction in survivin. By contrast, the overexpression of $\mathrm{B} 7-\mathrm{H} 3$ increased the phosphorylation of JAK2 and STAT3, indicating that the JAK2/STAT3 pathway contributes to B7-H3-mediated drug resistance (65) (Figure 3). Li et al. found that shRNA-mediated B7-H3 silencing inhibited AKT, ERK, and JAK2/STAT3 phosphorylation in the N87 gastric cancer cell line (28). Zhang et al. demonstrated that the overexpression of $\mathrm{B} 7-\mathrm{H} 3$ induced resistance to apoptosis in colorectal cancer cell lines by upregulating the JAK2-STAT3 signaling pathway; this effect thus potentially provides new approaches to the treatment of colorectal cancer (66). Recently, $\mathrm{Lu}$ et al. showed that B7-H3-mediated colon cancer cell resistance to the cytotoxicity of $\mathrm{V} \delta 2 \mathrm{~T}$ cells involved a molecular pathway comprising STAT3 activation and decreased ULBP2 expression (67). However, how B7-H3 activates the downstream JAK2/STAT3 pathway remains unknown, and its underlying mechanism remains a point of conjecture (68). Other novel mechanisms that remain undiscovered must be explored in future investigations.

\section{Glucose Metabolic Signaling Pathway}

B7-H3 also plays a crucial role in glucose metabolic reprogramming. Cancer cell metabolism is characterized by an increase in glycolysis and lactate production even in the presence of abundant oxygen; this phenomenon is known as the Warburg effect or aerobic glycolysis (69). Aerobic glycolysis confers a growth advantage to cancer cells by providing energy and biosynthetic building blocks (70). Lim et al. demonstrated that B7-H3 regulated glucose metabolism through ROS-mediated HIF1a stabilization, which contributed to B7-H3-enhanced tumor growth; B7-H3 suppresses NRF2 transcriptional activity, which in turn reduces transcription of the antioxidant enzymes SOD1, SOD2, and PRX3; B7-H3-induced ROS then stabilized HIF1 $\alpha$, thus increasing the expression of the glycolytic enzymes LDHA and PDK1, an effect that promoted pyruvate conversion into lactate while inhibiting pyruvate flux through the TCA cycle (71) (Figure 3), contributing to tumor metabolism microenvironment shaping (48). Moreover, in CRC cells, B7H3 mediated the activation of STAT3 and the subsequent expression of HK2 to promote glycolysis (72). 


\section{B7-H3-BASED TUMOR IMMUNOTHERAPY STRATEGIES}

Immunotherapy is a novel individualized treatment strategy wherein the immune system is activated or suppressed to amplify or diminish an immune response. It has been developed rapidly for the treatment of various forms of cancer in recent years. Immune-based therapies are gaining attention due to improvements in their clinical outcomes. The abnormal expression of B7-H3 is a possible biomarker and a promising immune checkpoint target for multiple cancer immunotherapy approaches, especially its expression on cancer initiating cells (CICs), since their eradication is a requirement for an anti-tumor therapy to be effective (73). Recent advances in molecular biology and antibody engineering have enabled targeting $\mathrm{B} 7-\mathrm{H} 3$ on the basis of multiple mechanisms. Information about clinical trials can be seen in Table 2 .

\section{Targeting B7-H3 With Blocking mAbs}

Blocking mAbs can partially or completely neutralize inhibitory ligand-to-receptor interactions, thus allowing effector functions (18). The use of blocking mAbs against the immune checkpoints CTLA-4, programmed cell death protein 1 (PD-1), and PD-1 ligand 1 (PD-L1) has demonstrated significant clinical success in patients with a variety of cancers (74-76). This successful experience can be applied to B7-H3 as well. B7-H3 blocking with $\mathrm{mAbs}$ has been shown to increase CD8+ T-cell and NK-cell tumor infiltration, reduce tumor growth, and prolong survival in mouse models of hematopoietic cancers, ovarian cancer (37), melanoma (77) and CRC (78). However, the translation of this

TABLE 2 | Summary of the clinical trials on anti B7-H3 antibodies for hematologic and solid tumor malignancies.

\begin{tabular}{|c|c|c|c|c|c|c|}
\hline Trial number & Description & Drug & $\begin{array}{l}\text { Trial } \\
\text { stage }\end{array}$ & Start date & $\begin{array}{l}\text { Completion } \\
\text { date }\end{array}$ & Status \\
\hline \multicolumn{7}{|c|}{ Targeting B7-H3 through ADCC } \\
\hline NCT01391143 & Refractory cancer, melanoma, prostate, solid tumors & $\begin{array}{l}\text { Enoblituzumab } \\
\text { (MGA271) }\end{array}$ & Phase I & July, 2011 & $\begin{array}{l}\text { April 18, } \\
2019\end{array}$ & Completed \\
\hline NCT02982941 & Pediatric patients with relapsed or refractory solid tumors & MGA271 & Phase I & $\begin{array}{l}\text { December, } \\
2016\end{array}$ & $\begin{array}{l}\text { May } 22 \text {, } \\
2019\end{array}$ & Completed \\
\hline NCT02923180 & Localized intermediate- and high-risk prostate cancer & MGA271 & Phase II & $\begin{array}{l}\text { October, } \\
2016\end{array}$ & $\begin{array}{l}\text { October, } \\
2021\end{array}$ & $\begin{array}{l}\text { Active but } \\
\text { not recruiting }\end{array}$ \\
\hline \multicolumn{7}{|c|}{ Targeting $\mathrm{B} 7-\mathrm{H} 3$ through ADC therapies } \\
\hline NCT03729596 & Advanced solid tumors & $\begin{array}{l}\text { MGC018 with or } \\
\text { without MGA012 }\end{array}$ & Phase I/II & $\begin{array}{l}\text { November } \\
21,2018\end{array}$ & May, 2025 & Recruiting \\
\hline NCT02475213 & $\begin{array}{l}\text { Patients with melanoma, squamous cell cancer of the head and neck, } \\
\text { NSCLC, and other cancers }\end{array}$ & $\begin{array}{l}\text { MGA271 with } \\
\text { pembrolizumab }\end{array}$ & Phase I & July, 2015 & $\begin{array}{l}\text { October, } \\
2022\end{array}$ & Recruiting \\
\hline \multicolumn{7}{|c|}{ Targeting B7-H3 with bispecific antibodies } \\
\hline NCT02628535 & Patients with unresectable or metastatic neoplasms & Orlotamab (MGD009) & Phase I & $\begin{array}{l}\text { September, } \\
2015\end{array}$ & $\begin{array}{l}\text { November } \\
25,2019\end{array}$ & Terminated \\
\hline \multicolumn{7}{|c|}{ Targeting B7-H3 with CAR T cells } \\
\hline NCT04185038 & $\begin{array}{c}\text { Diffuse Intrinsic Pontine Glioma/Diffuse Midline Glioma and Recurrent } \\
\text { or Refractory Pediatric Central Nervous System Tumors }\end{array}$ & - & Phase I & $\begin{array}{l}\text { December, } \\
2019\end{array}$ & May, 2041 & Recruiting \\
\hline NCT04077866 & Patients with Recurrent or Refractory Glioblastoma & - & $\begin{array}{l}\text { Phase I/ } \\
\text { Phase II }\end{array}$ & $\begin{array}{l}\text { May 1, } \\
2022\end{array}$ & July 1,2024 & Recruiting \\
\hline NCT04385173 & Patients with Recurrent and Refractory Glioblastoma & - & Phase I & $\begin{array}{l}\text { June } 1 \\
2020\end{array}$ & July 1, 2022 & Recruiting \\
\hline NCT04483778 & Recurrent/Refractory Solid Tumors in Children and Young Adults & - & Phase I & $\begin{array}{l}\text { July } 13, \\
2020\end{array}$ & $\begin{array}{l}\text { December, } \\
2040\end{array}$ & Recruiting \\
\hline \multicolumn{7}{|c|}{ Synergistic options with anti-B7-H3 therapies } \\
\hline NCT02381314 & Patients with melanoma, NSCLC, and other cancers & MGA271, ipilimumab & Phase I & $\begin{array}{l}\text { March 26, } \\
2015\end{array}$ & $\begin{array}{l}\text { September } \\
26,2018\end{array}$ & Completed \\
\hline NCT04129320 & Squamous Cell Carcinoma of the Head and Neck & MGA271, MGA012 & $\begin{array}{l}\text { Phase II/ } \\
\text { III }\end{array}$ & $\begin{array}{l}\text { October, } \\
2019\end{array}$ & $\begin{array}{l}\text { October, } \\
2025\end{array}$ & $\begin{array}{l}\text { Not yet } \\
\text { recruiting }\end{array}$ \\
\hline NCT02475213 & Safety Study in Refractory Cancer & $\begin{array}{l}\text { MGA271, } \\
\text { pembrolizumab or } \\
\text { MGA012 }\end{array}$ & Phase I & July, 2015 & $\begin{array}{l}\text { October, } \\
2022\end{array}$ & $\begin{array}{l}\text { Active but } \\
\text { not recruiting }\end{array}$ \\
\hline NCT03406949 & Relapsed/Refractory Cancer & MGD009/MGA012 & Phase I & $\begin{array}{l}\text { February } \\
27,2018\end{array}$ & $\begin{array}{l}\text { December, } \\
2022\end{array}$ & $\begin{array}{l}\text { Active but } \\
\text { not recruiting }\end{array}$ \\
\hline NCT01099644 & $\begin{array}{c}\text { Patients with Desmoplastic Small Round Cell Tumors and Other Solid } \\
\text { Tumors }\end{array}$ & ${ }^{131} \mathrm{I}-8 \mathrm{H} 9$ & Phase I & April, 2010 & $\begin{array}{l}\text { September, } \\
2020\end{array}$ & $\begin{array}{l}\text { Active but } \\
\text { not recruiting }\end{array}$ \\
\hline NCT04022213 & $\begin{array}{c}\text { Patients with Desmoplastic Small Round Cell Tumors and Other Solid } \\
\text { Tumors }\end{array}$ & ${ }^{131} \mathrm{I}-8 \mathrm{H} 9$ & Phase II & $\begin{array}{l}\text { July } 15 \\
2019\end{array}$ & July 2024 & Recruiting \\
\hline NCT04167618 & Recurrent or Refractory Medulloblastoma & ${ }^{177}$ Lu-DTPA-8H9 & $\begin{array}{l}\text { Phase 1/ } \\
\text { Phase } 2\end{array}$ & $\begin{array}{l}\text { January 15, } \\
2021\end{array}$ & $\begin{array}{l}\text { December } \\
15,2024\end{array}$ & $\begin{array}{l}\text { Not yet } \\
\text { recruiting }\end{array}$ \\
\hline NCT04315246 & Leptomeningeal Metastasis from Solid Tumors & ${ }^{177}$ Lu-DTPA-8H9 & $\begin{array}{l}\text { Phase 1/ } \\
\text { Phase } 2\end{array}$ & $\begin{array}{l}\text { December } \\
31,2020\end{array}$ & $\begin{array}{l}\text { December } \\
31,2024\end{array}$ & $\begin{array}{l}\text { Not yet } \\
\text { recruiting }\end{array}$ \\
\hline
\end{tabular}

Not all clinical studies were included in this table due to the space limitation. 
strategy into the clinical setting has been hampered by the lack of human B7-H3-specific blocking mAbs.

\section{Targeting B7-H3 Through ADCC}

Antibody-dependent cell-mediated cytotoxicity (ADCC) refers to the binding of the antibody Fab to malignant cells. Moreover, Fc can bind to FcR on the surfaces of killer cells to mediate the direct killing of target cells. Loo et al. developed MGA271, a B7$\mathrm{H} 3$-reactive, Fc-engineered $\mathrm{mAb}$ that mediates potent antitumor activity in vitro and in tumor xenografts; this characteristic, together with the favorable safety profile of MGA271 in cynomolgus monkey toxicology studies, supports its exploration in the treatment of B7H3-positive cancers (79) (Figure 4).

\section{Targeting B7-H3 Through Antibody-Drug Conjugates Therapies}

Antibody-drug conjugates (ADCs) combine the target specificity of a mAb with cytotoxic agents to deliver the cytotoxic agents to a tumor and improve therapeutic indexes. Scribner et al. developed MGC018, an anti-B7-H3 ADC that incorporated an aduocarmycin-based DNA alkylating payload via a cleavable valine-citrulline linker. MGC018 exhibited potent antitumor activity in a range of human tumor xenografts, mediated bystander killing, and showed a favorable safety profile in cynomolgus monkeys (80).

\section{Targeting B7-H3 With CD3-Engaging Bispecific Antibodies}

Bispecific antibodies (BsAbs) are another option that is beginning to pick up steam in the area of tumor immunotherapy. BsAbs are artificially generated antibodies that are composed of the fragments of two distinct Abs and combining two specificities. One arm can bind to the CD3 component of the TCR complex on T cells, whereas the other arm recognizes a tumor-specific antigen, such as $\mathrm{B} 7-\mathrm{H} 3$. In this way, $\mathrm{T}$ cells are recruited to the tumor site and activated to kill cancer cells (81). The anti-CD3 antibody that is chemically conjugated with the anti-B7-H3 mAb antibody has been clinically approved (82). The anti-CD3 $\times$ anti-B7-H3 bispecific antibody (B7-H3 Bi-Ab) was then used to direct activated $\mathrm{T}$ cells

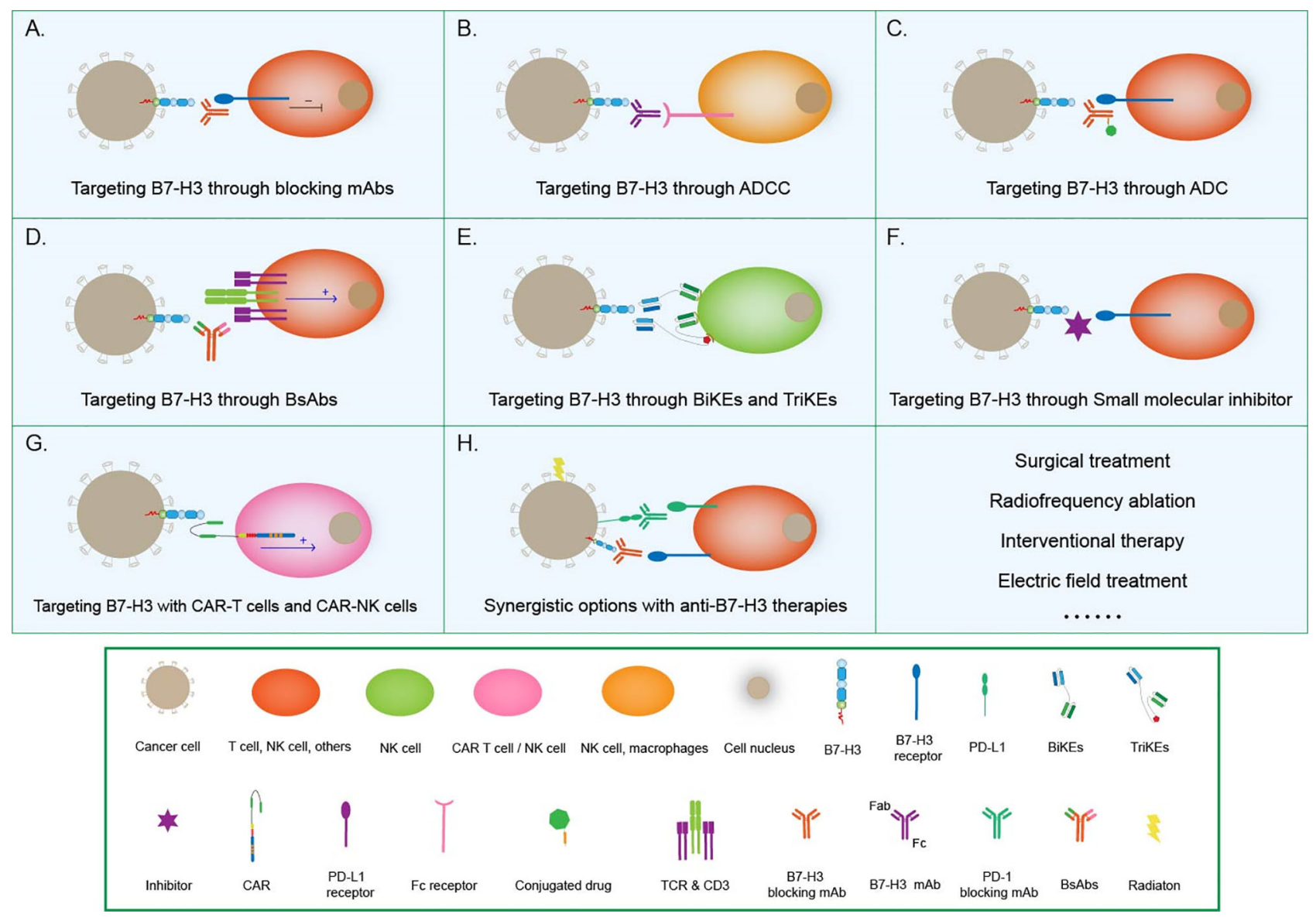

FIGURE 4 | Tumor immunotherapy strategies based on B7-H3. (A) Targeting B7-H3 with blocking mAbs; (B) Targeting B7-H3 through ADCC; (C) Targeting B7-H3 through ADC therapies; (D) Targeting B7-H3 with CD3-engaging BsAbs; (E) BiKEs and TriKEs; (F) Targeting B7-H3 with small-molecule inhibitors; (G) Targeting B7$\mathrm{H} 3$ with CAR T cells and CAR-NK cells; (H) Synergistic options with anti B7-H3 therapies. 
to kill tumor targets (83). The activated T cell armed with B7-H3 $\mathrm{Bi}-\mathrm{Ab}$ exhibited increased specific cytotoxicity and cytokine production and suppressed B7-H3-positive cancer growth in the SCID-Beige murine model.

\section{Bi and Tri-Specific Killer Engagers}

Bispecific killer engagers (BiKEs) or trispecific killer engagers (TriKEs) form an antigen-specific immunological synapse between NK and tumor cells, thereby triggering NK-cellmediated tumor cell lysis. BiKEs consist of an anti-CD16 scFv linked to an $\mathrm{scFv}$ that is specific for a tumor-expressed antigen, and TriKEs comprise the two scFvs mentioned above and a cytokine, most frequently IL-15 (84). Vallera et al. generated a B7-H3/IL-15 TriKE that used the scFv of the B7-H3-specific mAb 376.96; when deployed against PDAC, this TriKE resulted in a significant reduction in tumor load in vitro and in murine models (85). The same group had bioengineered a secondgeneration TriKE with human IL-15 as a modified crosslinker between an anti-B7-H3 scFv and a humanized camelid antiCD16 single domain antibody. The latter allowed the improved function of IL15, thus enhancing the activation and proliferation of NK cells and the killing of ovarian cancer cells in vitro and in murine models (86).

\section{Targeting B7-H3 With Small-Molecule Inhibitors}

In addition to conventional therapeutic mAbs, small-molecule inhibitors have also begun to capture interest in the immuneoncology field (87). Small-molecule inhibitors are lowmolecular-weight organic compounds (dinucleotides and peptides) that bind to specific biological targets, blocking specific antigen-antibody binding. They are readily used because of their advantages, including cheap manufacturing costs, ease of delivery due to their oral administration route, excellent tissue distribution due to their size, and short half-lives, over antibodies. A small-molecule inhibitor can be designed on the basis of the FG loop of the IgV domain of B7-H3 that is involved in T-cell activation to target this specific ligation area (88). Small molecule immunotherapy can provide an alternative treatment modality either alone or complementary to or synergistic with extracellular checkpoint mAbs to address low clinical response and drug resistance. The future research should continue to focus on discovery of novel small molecules with distinct chemo-types and higher potency (89).

\section{Targeting B7-H3 With Chimeric Antigen Receptor T Cells and Chimeric Antigen Receptor NK Cells}

Chimeric antigen receptor (CAR) T-cell technology is another effective way to target B7-H3 for immunotherapy. Autologous T cells or NK cells are engineered with a CAR that targets a tumor antigen and adoptively transferred to patients to kill cancer cells. Thus far, this technology has been successfully applied only in hematologic cancers. Although this area of research is challenging, efforts are being made to translate CAR-T cell therapy into the treatment of solid tumors (18). B7-H3- redirected CAR-T cells can effectively control GBM growth $(90,91)$ and are highly active against atypical teratoma-like rhabdomyoma in vitro and in xenograft murine models (92). Majzner et al. reported a CAR-T cell system directed at B7-H3 with strong activity against a wide array of xenograft pediatric cancer models, including liquid, solid, and central nervous system (CNS) tumors; they also demonstrated that, as has emerged for many CAR therapeutics, CAR T cell activity is dependent on antigen density (38). Furthermore, Yang et al. developed a tandem CAR T cell system that exhibited enhanced antitumor activity and tumor control in several preclinical models (93). Tang et al. presented the results of the first-inhuman clinical study on B7-H3-targeted CAR T cells for the treatment of recurrent anaplastic meningioma and provided evidence that the local delivery of B7-H3-targeted CAR T cells could suppress tumor progression without off-tumor toxicity or serious side effects, thus indicating the tolerability, safety, and potential efficacy of this therapy (94). Recently, NK-cells have been used to generate CAR-NK cells, which controlled the growth of human NSCLC cells grafted in murine models and prolonged survival (95). Lei et al. reported that a pan-histone deacetylase inhibitor can enhance the antitumor activity of B7H3-specific CAR T cells in solid tumors (96).

\section{Synergistic Options With Anti-B7-H3 Therapies}

With the successful experience of traditional immunotherapy, Combination therapy for improving the effect of immunotherapy and the survival rate of patients through combination of different immunotherapies has attracted increasing attention. Recent studies have shown that the combination of a variety of chemotherapeutics with checkpoint inhibitors exerts great synergistic effects that enhance the prospects of their full utilization in standard clinical practice.

Combination therapy involving multiple immune checkpoint inhibitors is emerging rapidly as a means for cancer treatment. Larkin et al. found that in patients with PD-L1-negative tumors, the combination of Nivolumab (PD-1 blockade) and ipilimumab (CTLA-4 blockade) was more effective than either agent alone (97). Xu et al. developed anti-B7-H3/PD-1 bispecific fusion proteins that simultaneously engaged the tumor-associated marker B7-H3 and the immune-suppressing ligand PD-L1 and enhanced ADCC to promote potent and highly selective tumor killing (98). Yonesaka et al. discovered that anti-B7-H3 immunotherapy combined with anti-PD-1/PD-L1 antibody therapy is a promising approach for the treatment of B7-H3expressing NSCLCs (24).

$\mathrm{B} 7-\mathrm{H} 3$ gene silencing and combination drug therapy can also improve the rate of tumor elimination. Zhang et al. demonstrated that in U937 cells, B7-H3-targeting shRNA significantly enhanced sensitivity to chemotherapeutic drugs (99). Liu et al. examined the role of B7-H3 in paclitaxel resistance in several metastatic breast cancer cell lines; their results indicated that the B7-H3-shRNAinduced knockdown of the $\mathrm{B} 7-\mathrm{H} 3$ protein in these cells resulted in increased sensitivity to paclitaxel (65). Both studies showed that silencing B7-H3 significantly enhanced tumor cell chemosensitivity 
and drug-induced apoptosis, thus providing a rationale for the potential synergistic effects between the B7-H3 blockade and chemotherapy or targeted therapy for patients with a variety of cancers.

Radiation is an additional avenue that can be considered for application in a future clinical setting in combination with B7H3 targeting. Twyman-Saint Victor et al. demonstrated that PDL1 on melanoma cells allowed tumors to escape anti-CTLA4based therapy, and the combination of radiation, anti-CTLA4, and anti-PD-L1 promoted response and immunity through distinct mechanisms (100). 8H9 is distinct from other B7-H3specific antibodies in that it binds to the FG loop of B7-H3, a region that is critical to its immunologic function (101).

Given the multiple steps involved in anticancer immunity, the potential to enhance cancer immunotherapy via rational combinations by modulating different biological steps in immunity simultaneously or in rapid sequence is quite broad (102). Besides immunotherapies, some non-immunotherapies such as surgical treatment (103), radiofrequency ablation (104), interventional therapy (105), electric field treatment (106) should been also taken into consideration.

\section{CONCLUSIONS AND OUTLOOK}

B7-H3 is a novel immune checkpoint from the B7 family. In this review, we analyzed the transcription and expression levels of B7-H3 in different tumors by utilizing bioinformatics tools, provided a comprehensive view of $\mathrm{B} 7-\mathrm{H} 3$ 's role in the TME, and summarized different B7-H3-based cancer immunotherapy strategies along with their corresponding clinical trials. The prospect of $\mathrm{B} 7-\mathrm{H} 3$ as a target for cancer immunotherapy which stems from its special expression patterns on tumor cells and the safety profile has stimulated the progress of B7-H3targeting therapeutic strategies. The success of immunotherapies such as targeting PD-1 and CTLA4, also provide researchers' example and direction to develop new immunotherapy that target B7-H3. However, the unknown identity of the B7-H3 receptor greatly hinders the development of B7-H3 antagonists. Improving the understanding of $\mathrm{B} 7-\mathrm{H} 3$-mediated molecular processes for the regulation of tumorigenesis will open new avenues for developing novel therapeutic strategies for human cancers. Notably, organoids have attracted increasing attention in tumor research in recent years given their advantageous capability to reproduce tissue structure and organ function. The future trend of tumor immunotherapy involves studying cell therapy in different organoids on the basis of the new immune checkpoint B7-H3. To develop the diagnostic and therapeutic potential of B7-H3 completely, its expression in serum, pre-malignant lesions, tumor-associated vasculature, CSC, CIC, metastases and recurrence requires further investigation. Future studies aiming to delineate the precise cellular and molecular mechanisms based on B7-H3-mediated tumor promotion will provide further insights into the cell biology of tumor development and cancer immunotherapy.

\section{AUTHOR CONTRIBUTIONS}

The corresponding author W-LJ instructed the manuscript completion. The first author $\mathrm{W}-\mathrm{TZ}$ contributed to manuscript writing and revising. All authors contributed to the article and approved the submitted version.

\section{FUNDING}

This study was supported by grants from the National Key Research and Development Program of China (no. 2017FYA0205302) to W-LJ.

\section{REFERENCES}

1. Egen JG, Ouyang W, Wu LC. Human Anti-Tumor Immunity: Insights From Immunotherapy Clinical Trials. Immunity (2020) 52:36-54. doi: 10.1016/j.immuni.2019.12.010

2. Sanmamed MF, Chen L. A Paradigm Shift in Cancer Immunotherapy: From Enhancement to Normalization. Cell (2018) 175:313-26. doi: 10.1016/ j.cell.2018.09.035

3. Li G, Quan Y, Che F, Wang L. B7-H3 in Tumors: Friend or Foe for Tumor Immunity? Cancer Chemother Pharmacol (2018) 81:245-53. doi: 10.1007/ s00280-017-3508-1

4. Loos M, Hedderich DM, Friess H, Kleeff J. B7-H3 and Its Role in Antitumor Immunity. Clin Dev Immunol (2010) 2010:683875. doi: 10.1155/2010/ 683875

5. Pollizzi KN, Powell JD. Integrating Canonical and Metabolic Signalling Programmes in the Regulation of $\mathrm{T}$ Cell Responses. Nat Rev Immunol (2014) 14:435-46. doi: 10.1038/nri3701

6. Zang X, Allison JP. The B7 Family and Cancer Therapy: Costimulation and Coinhibition. Clin Cancer Res (2007) 13:5271-9. doi: 10.1158/10780432.CCR-07-1030

7. Hofmeyer KA, Ray A, Zang X. The Contrasting Role of B7-H3. Proc Natl Acad Sci USA (2008) 105:10277-8. doi: 10.1073/pnas.0805458105

8. Chapoval AI, Ni J, Lau JS, Wilcox RA, Flies DB, Liu D, et al. B7-H3: A Costimulatory Molecule for T Cell Activation and IFN-Gamma Production. Nat Immunol (2001) 2:269-74. doi: 10.1038/85339

9. Zou W, Chen L. Inhibitory B7-Family Molecules in the Tumour Microenvironment. Nat Rev Immunol (2008) 8:467-77. doi: 10.1038/nri2326

10. Sun M, Richards S, Prasad DV, Mai XM, Rudensky A, Dong C. Characterization of Mouse and Human B7-H3 Genes. J Immunol (2002) 168:6294-7. doi: 10.4049/jimmunol.168.12.6294

11. Steinberger P, Majdic O, Derdak SV, Pfistershammer K, Kirchberger S, Klauser C, et al. Molecular Characterization of Human 4Ig-B7-H3, a Member of the B7 Family With Four Ig-like Domains. J Immunol (2004) 172:2352-9. doi: 10.4049/jimmunol.172.4.2352

12. Chen W, Liu P, Wang Y, Nie W, Li Z, Xu W, et al. Characterization of a Soluble B7-H3 (sB7-H3) Spliced From the Intron and Analysis of sB7-H3 in the Sera of Patients With Hepatocellular Carcinoma. PloS One (2013) 8: e76965. doi: 10.1371/journal.pone.0076965

13. Zhang G, Hou J, Shi J, Yu G, Lu B, Zhang X. Soluble CD276 (B7-H3) is Released From Monocytes, Dendritic Cells and Activated T Cells and is Detectable in Normal Human Serum. Immunology (2008) 123:538-46. doi: 10.1111/j.1365-2567.2007.02723.x

14. Flem-Karlsen K, Tekle C, Andersson Y, Flatmark K, Fodstad O, NunesXavier CE. Immunoregulatory Protein B7-H3 Promotes Growth and 
Decreases Sensitivity to Therapy in Metastatic Melanoma Cells. Pigm Cell Melanoma R (2017) 30:467-76. doi: 10.1111/pcmr.12599

15. Purvis IJ, Velpula KK, Guda MR, Nguyen D, Tsung AJ, Asuthkar S. B7-H3 in Medulloblastoma-Derived Exosomes; A Novel Tumorigenic Role. Int J Mol Sci (2020) 21:7050. doi: 10.3390/ijms21197050

16. Hashiguchi M, Kobori H, Ritprajak P, Kamimura Y, Kozono H, Azuma M. Triggering Receptor Expressed on Myeloid Cell-Like Transcript 2 (TLT-2) is a Counter-Receptor for B7-H3 and Enhances T Cell Responses. P Natl Acad Sci USA (2008) 105:14744-4. doi: 10.1073/pnas.0807700105. (vol 105, pg 10495, 2008).

17. Yang S, Wei W, Zhao Q. B7-H3, a Checkpoint Molecule, as a Target for Cancer Immunotherapy. Int J Biol Sci (2020) 16:1767-73. doi: 10.7150/ ijbs.41105

18. Picarda E, Ohaegbulam KC, Zang X. Molecular Pathways: Targeting B7-H3 (CD276) for Human Cancer Immunotherapy. Clin Cancer Res (2016) 22:3425-31. doi: 10.1158/1078-0432.CCR-15-2428

19. Flem-Karlsen K, Fodstad O, Tan M, Nunes-Xavier CE. B7-H3 in Cancer Beyond Immune Regulation. Trends Cancer (2018) 4:401-4. doi: 10.1016/ j.trecan.2018.03.010

20. Wang L, Kang FB, Sun N, Wang J, Chen W, Li D, et al. The Tumor Suppressor miR-124 Inhibits Cell Proliferation and Invasion by Targeting B7-H3 in Osteosarcoma. Tumour Biol (2016) 37:14939-47. doi: 10.1007/ s13277-016-5386-2

21. Purvis IJ, Avilala J, Guda MR, Venkataraman S, Vibhakar R, Tsung AJ, et al. Role of MYC-miR-29-B7-H3 in Medulloblastoma Growth and Angiogenesis. J Clin Med (2019) 8:1158. doi: 10.3390/jcm8081158

22. Hu X, Xu M, Hu Y, Li N, Zhou L. B7-H3, Negatively Regulated by Mir-128, Promotes Colorectal Cancer Cell Proliferation and Migration. Cell Biochem Biophys (2021) 79:397-405. doi: 10.1007/s12013-021-00975-0

23. Cong F, Yu H, Gao X. Expression of CD24 and B7-H3 in Breast Cancer and the Clinical Significance. Oncol Lett (2017) 14:7185-90. doi: 10.3892/ ol.2017.7142

24. Yonesaka K, Haratani K, Takamura S, Sakai H, Kato R, Takegawa N, et al. B7-H3 Negatively Modulates CTL-Mediated Cancer Immunity. Clin Cancer Res (2018) 24:2653-64. doi: 10.1158/1078-0432.CCR-17-2852

25. Zang X, Sullivan PS, Soslow RA, Waitz R, Reuter VE, Wilton A, et al. Tumor Associated Endothelial Expression of B7-H3 Predicts Survival in Ovarian Carcinomas. Mod Pathol (2010) 23:1104-12. doi: 10.1038/modpathol.2010.95

26. Proctor DT, Patel Z, Lama S, Resch L, van Marle G, Sutherland GR. Identification of PD-L2, B7-H3 and CTLA-4 Immune Checkpoint Proteins in Genetic Subtypes of Meningioma. Oncoimmunology (2019) 8: e1512943. doi: 10.1080/2162402X.2018.1512943

27. Deng J, Ma M, Wang D, Zhu H, Hua L, Sun S, et al. Expression and Clinical Significance of Immune Checkpoint Regulator B7-H3 (CD276) in Human Meningioma. World Neurosurg (2020) 135:e12-8. doi: 10.1016/j.wneu. 2019.10.044

28. Li Y, Yang X, Wu Y, Zhao K, Ye Z, Zhu J, et al. B7-H3 Promotes Gastric Cancer Cell Migration and Invasion. Oncotarget (2017) 8:71725-35. doi: 10.18632/oncotarget.17847

29. Wang L, Cao NN, Wang S, Man HW, Li PF, Shan BE. Roles of Coinhibitory Molecules B7-H3 and B7-H4 in Esophageal Squamous Cell Carcinoma. Tumour Biol (2016) 37:2961-71. doi: 10.1007/s13277-015-4132-5

30. Varki V, Ioffe OB, Bentzen SM, Heath J, Cellini A, Feliciano J, et al. Pd-L1, B7-H3, and PD-1 Expression in Immunocompetent vs. Immunosuppressed Patients With Cutaneous Squamous Cell Carcinoma. Cancer Immunol Immunother (2018) 67:805-14. doi: 10.1007/s00262-018-2138-8

31. Ferlay J, Soerjomataram I, Dikshit R, Eser S, Mathers C, Rebelo M, et al. Cancer Incidence and Mortality Worldwide: Sources, Methods and Major Patterns in GLOBOCAN 2012. Int J Cancer (2015) 136:E359-386. doi: $10.1002 /$ ijc. 29210

32. Wilson KE, Bachawal SV, Abou-Elkacem L, Jensen K, Machtaler S, Tian L, et al. Spectroscopic Photoacoustic Molecular Imaging of Breast Cancer Using a B7-H3-targeted Icg Contrast Agent. Theranostics (2017) 7:146376. doi: $10.7150 /$ thno. 18217

33. Arigami T, Narita N, Mizuno R, Nguyen L, Ye X, Chung A, et al. B7-H3 Ligand Expression by Primary Breast Cancer and Associated With Regional Nodal Metastasis. Ann Surg (2010) 252:1044-51. doi: 10.1097/SLA. 0b013e3181f1939d
34. Castellanos JR, Purvis IJ, Labak CM, Guda MR, Tsung AJ, Velpula KK, et al. B7-H3 Role in the Immune Landscape of Cancer. Am J Clin Exp Immunol (2017) 6:66-75.

35. Li F, Chen H, Wang D. Silencing of CD276 Suppresses Lung Cancer Progression by Regulating Integrin Signaling. J Thorac Dis (2020) 12:2137-45. doi: 10.21037/jtd.2020.04.41

36. MacGregor HL, Sayad A, Elia A, Wang BX, Katz SR, Shaw PA, et al. High Expression of B7-H3 on Stromal Cells Defines Tumor and Stromal Compartments in Epithelial Ovarian Cancer and Is Associated With Limited Immune Activation. J Immunother Cancer (2019) 7:357. doi: 10.1186/s40425-019-0816-5

37. Cai DL, Li JM, Liu DF, Hong SJ, Qiao Q, Sun QL, et al. Tumor-Expressed B7-H3 Mediates the Inhibition of Antitumor T-Cell Functions in Ovarian Cancer Insensitive to PD-1 Blockade Therapy. Cell Mol Immunol (2020) 17:227-36. doi: 10.1038/s41423-019-0305-2

38. Majzner RG, Theruvath JL, Nellan A, Heitzeneder S, Cui Y, Mount CW, et al. Car T Cells Targeting B7-H3, a Pan-Cancer Antigen, Demonstrate Potent Preclinical Activity Against Pediatric Solid Tumors and Brain Tumors. Clin Cancer Res (2019) 25:2560-74. doi: 10.1158/1078-0432. CCR-18-0432

39. Wang ZX, Yang JF, Zhu YB, Zhu Y, Zhang B, Zhou YH. Differential Expression of 2igB7-H3 and 4igB7-H3 in Cancer Cell Lines and Glioma Tissues. Oncol Lett (2015) 10:2204-8. doi: 10.3892/ol.2015.3611

40. Aung PP, Parra ER, Barua S, Sui D, Ning J, Mino B, et al. B7-H3 Expression in Merkel Cell Carcinoma-Associated Endothelial Cells Correlates With Locally Aggressive Primary Tumor Features and Increased Vascular Density. Clin Cancer Res (2019) 25:3455-67. doi: 10.1158/1078-0432.CCR-18-2355

41. Suh WK, Gajewska BU, Okada H, Gronski MA, Bertram EM, Dawicki W, et al. The B7 Family Member B7-H3 Preferentially Down-Regulates T Helper Type 1-Mediated Immune Responses. Nat Immunol (2003) 4:899906. doi: $10.1038 /$ ni967

42. Suh WK, Wang SX, Jheon AH, Moreno L, Yoshinaga SK, Ganss B, et al. The Immune Regulatory Protein B7-H3 Promotes Osteoblast Differentiation and Bone Mineralization. Proc Natl Acad Sci USA (2004) 101:12969-73. doi: 10.1073/pnas.0405259101

43. Lupu CM, Eisenbach C, Kuefner MA, Schmidt J, Lupu AD, Stremmel W, et al. An Orthotopic Colon Cancer Model for Studying the B7-H3 Antitumor Effect In Vivo. J Gastrointest Surg (2006) 10:635-45. doi: 10.1007/BF03239969

44. Lupu CM, Eisenbach C, Lupu AD, Kuefner MA, Hoyler B, Stremmel W, et al. Adenoviral B7-H3 Therapy Induces Tumor Specific Immune Responses and Reduces Secondary Metastasis in a Murine Model of Colon Cancer. Oncol Rep (2007) 18:745-8. doi: 10.3892/or.18.3.745

45. Prasad DVR, Nguyen T, Li ZX, Yang Y, Duong J, Wang Y, et al. Murine B7H3 is a Negative Regulator of T Cells. J Immunol (2004) 173:2500-6. doi: 10.4049/jimmunol.173.4.2500

46. Castriconi R, Dondero A, Augugliaro R, Cantoni C, Carnemolla B, Sementa $\mathrm{AR}$, et al. Identification of 4Ig-B7-H3 as a Neuroblastoma-Associated Molecule That Exerts a Protective Role From an NK Cell-Mediated Lysis. Proc Natl Acad Sci USA (2004) 101:12640-5. doi: 10.1073/pnas. 0405025101

47. Wang C, Li Y, Jia L, Kim JK, Li J, Deng P, et al. CD276 Expression Enables Squamous Cell Carcinoma Stem Cells to Evade Immune Surveillance. Cell Stem Cell (2021) 28:1-17. doi: 10.1016/j.stem.2021.04.011

48. Jin MZ, Jin WL. The Updated Landscape of Tumor Microenvironment and Drug Repurposing. Signal Transduct Target Ther (2020) 5:166. doi: 10.1038/ s41392-020-00280-X

49. Li H, Zhang B, Liu Y, Yin C. EBP50 Inhibits the Migration and Invasion of Human Breast Cancer Cells Via LIMK/Cofilin and the PI3K/Akt/mTOR/ MMP Signaling Pathway. Med Oncol (2014) 31:162. doi: 10.1007/s12032014-0162-x

50. Niu H, Wu B, Peng Y, Jiang H, Zhang Y, Wang J, et al. RNA InterferenceMediated Knockdown of RhoGDI2 Induces the Migration and Invasion of Human Lung Cancer A549 Cells Via Activating the PI3K/Akt Pathway. Tumour Biol (2015) 36:409-19. doi: 10.1007/s13277-014-2671-9

51. Wu XY, Chen Y, Li G, Xia L, Gu RM, Wen X, et al. Her3 is Associated With Poor Survival of Gastric Adenocarcinoma: Her3 Promotes Proliferation, Survival and Migration of Human Gastric Cancer Mediated by PI3K/AKT 
Signaling Pathway. Med Oncol (2014) 31:1-11. doi: 10.1007/s12032-0140903-x

52. El Hage A, Dormond O. Combining Mtor Inhibitors and T Cell-Based Immunotherapies in Cancer Treatment. Cancers (Basel) (2021) 13:1359. doi: $10.3390 /$ cancers 13061359

53. Li YC, Guo GN, Song J, Cai ZP, Yang J, Chen ZW, et al. B7-H3 Promotes the Migration and Invasion of Human Bladder Cancer Cells Via the PI3K/Akt/ STAT3 Signaling Pathway. J Cancer (2017) 8:816-24. doi: 10.7150/jca.17759

54. Nunes-Xavier CE, Karlsen KF, Tekle C, Pedersen C, Oyjord T, Hongisto V, et al. Decreased Expression of B7-H3 Reduces the Glycolytic Capacity and Sensitizes Breast Cancer Cells to AKT/mTOR Inhibitors. Oncotarget (2016) 7:6891-901. doi: 10.18632/oncotarget.6902

55. Jiang B, Zhang T, Liu F, Sun ZZ, Shi HP, Hua D, et al. The Co-Stimulatory Molecule B7-H3 Promotes the Epithelial-Mesenchymal Transition in Colorectal Cancer. Oncotarget (2016) 7:31755-71. doi: 10.18632/ oncotarget.9035

56. Napetschnig J, Wu H. Molecular Basis of NF-kappaB Signaling. Annu Rev Biophys (2013) 42:443-68. doi: 10.1146/annurev-biophys-083012-130338

57. Wang RQ, Ma YC, Zhan SH, Zhang GB, Cao L, Zhang XG, et al. B7-H3 Promotes Colorectal Cancer Angiogenesis Through Activating the NFKappa B Pathway to Induce VEGFA Expression. Cell Death Dis (2020) 11:55. doi: 10.1038/s41419-020-2252-3

58. Xie C, Liu DQ, Chen QJ, Yang C, Wang B, Wu HS. Soluble B7-H3 Promotes the Invasion and Metastasis of Pancreatic Carcinoma Cells Through the TLR4/NF-Kappa B Pathway. Sci Rep (2016) 6:27528. doi: 10.1038/srep27528

59. Qi MS, Elion EA. MAP Kinase Pathways. J Cell Sci (2005) 118:3569-72. doi: $10.1242 /$ jcs. 02470

60. Flem-Karlsen K, Tekle C, Oyjord T, Florenes VA, Maelandsmo GM, Fodstad O, et al. P38 MAPK Activation Through B7-H3-Mediated DUSP10 Repression Promotes Chemoresistance. Sci Rep-Uk (2019) 9:5839. doi: 10.1038/s41598-019-42303-w

61. Girardi T, Sulima SO, Vereecke S, Khan Y, Fancello L, Flickinger Z, et al. The T-Cell Leukemia Associated Ribosomal Rpl10 R98s Mutation Enhances JakStat Signaling. Haematologica (2017) 102:159-9. doi: 10.1038/leu.2017.225

62. Raible DJ, Frey LC, Brooks-Kayal AR. Effects of JAK2-STAT3 Signaling After Cerebral Insults. JAKSTAT (2014) 3:e29510. doi: 10.4161/jkst.29510

63. Capalbo G, Dittmann K, Hausmann E, Weiss C, Rodel C, Rodel F. Survivin As A Novel Target Protein for Reducing the Proliferation of Cancer Cells. Strahlenther Onkol (2009) 185:157-7. doi: 10.3892/br.2018.1077

64. Buki A, Okonkwo DO, Wang KKW, Povlishock JT. Cytochrome C Release and Caspase Activation in Traumatic Axonal Injury. J Neurosci (2000) 20:2825-34. doi: 10.1523/JNEUROSCI.20-08-02825.2000

65. Liu H, Tekle C, Chen YW, Kristian A, Zhao YH, Zhou M, et al. B7-H3 Silencing Increases Paclitaxel Sensitivity by Abrogating Jak2/Stat3 Phosphorylation. Mol Cancer Ther (2011) 10:960-71. doi: 10.1158/15357163.Mct-11-0072

66. Zhang T, Jiang B, Zou ST, Liu F, Hua D. Overexpression of B7-H3 Augments Anti-Apoptosis of Colorectal Cancer Cells by Jak2-STAT3. World J Gastroenterol (2015) 21:1804-13. doi: 10.3748/wjg.v21.i6.1804

67. Lu H, Ma Y, Wang M, Shen J, Wu H, Li J, et al. B7-H3 Confers Resistance to Vgamma9Vdelta2 T Cell-Mediated Cytotoxicity in Human Colon Cancer Cells Via the STAT3/ULBP2 Axis. Cancer Immunol Immunother (2021) 70:1213-26. doi: 10.1007/s00262-020-02771-w

68. Yang SY, Sales KM, Fuller B, Seifalian AM, Winslet MC. Apoptosis and Colorectal Cancer: Implications for Therapy. Trends Mol Med (2009) 15:225-33. doi: 10.1016/j.molmed.2009.03.003

69. Hanahan D, Weinberg RA. Hallmarks of Cancer: The Next Generation. Cell (2011) 144:646-74. doi: 10.1016/j.cell.2011.02.013

70. Heiden MGV, Cantley LC, Thompson CB. Understanding the Warburg Effect: The Metabolic Requirements of Cell Proliferation. Science (2009) 324:1029-33. doi: 10.1126/science.1160809

71. Lim S, Liu H, da Silva LM, Arora R, Liu ZX, Phillips JB, et al. Immunoregulatory Protein B7-H3 Reprograms Glucose Metabolism in Cancer Cells by ROS-Mediated Stabilization of HIF1 Alpha. Cancer Res (2016) 76:2231-42. doi: 10.1158/0008-5472.Can-15-1538

72. Shi T, Ma Y, Cao L, Chen W, Zhang X. B7-H3 Promotes Aerobic Glycolysis and Chemoresistance in Colorectal Cancer Cells by Regulating HK2. Eur $J$ Immunol (2019) 49:95-5. doi: 10.1038/s41419-019-1549-6
73. Michelakos T, Kontos F, Barakat O, Maggs L, Schwab JH, Ferrone CR, et al. B7-H3 Targeted Antibody-Based Immunotherapy of Malignant Diseases. Expert Opin Biol Ther (2021) 21:587-602. doi: 10.1080/14712598. 2021.1862791

74. Brahmer JR, Tykodi SS, Chow LQM, Hwu WJ, Topalian SL, Hwu P, et al. Safety and Activity of Anti-PD-L1 Antibody in Patients With Advanced Cancer. New Engl J Med (2012) 366:2455-65. doi: 10.1056/NEJMoa1200694

75. Hodi FS, O’Day SJ, McDermott DF, Weber RW, Sosman JA, Haanen JB, et al. Improved Survival With Ipilimumab in Patients With Metastatic Melanoma. N Engl J Med (2010) 363:711-23. doi: 10.1056/NEJMoa1003466

76. Topalian SL, Hodi FS, Brahmer JR, Gettinger SN, Smith DC, McDermott DF, et al. Safety, Activity, and Immune Correlates of Anti-PD-1 Antibody in Cancer. New Engl J Med (2012) 366:2443-54. doi: 10.1056/NEJMoa1200690

77. Lee YH, Martin-Orozco N, Zheng PL, Li J, Zhang P, Tan HD, et al. Inhibition of the B7-H3 Immune Checkpoint Limits Tumor Growth by Enhancing Cytotoxic Lymphocyte Function. Cell Res (2017) 27:1034-45. doi: $10.1038 /$ cr.2017.90

78. Lu H, Shi T, Wang M, Li X, Gu Y, Zhang X, et al. B7-H3 Inhibits the IFNgamma-dependent Cytotoxicity of Vgamma9Vdelta2 T Cells Against Colon Cancer Cells. Oncoimmunology (2020) 9:1748991. doi: 10.1080/ 2162402X.2020.1748991

79. Loo D, Alderson RF, Chen FZ, Huang L, Zhang WJ, Gorlatov S, et al. Development of an Fc-Enhanced Anti-B7-H3 Monoclonal Antibody With Potent Antitumor Activity. Clin Cancer Res (2012) 18:3834-45. doi: 10.1158/ 1078-0432.Ccr-12-0715

80. Scribner JA, Brown JG, Sharma S, Li H, Chiechi M, Li P, et al. Preclinical Development of MGC018, a Duocarmycin-Based Antibody-Drug Conjugate Targeting B7-H3 for Solid Cancer. Cancer Res (2018) 78:820. doi: 10.1158/ 1538-7445.AM2018-820

81. Weidle UH, Kontermann RE, Brinkmann U. Tumor-Antigen-Binding Bispecific Antibodies for Cancer Treatment. Semin Oncol (2014) 41:65360. doi: 10.1053/j.seminoncol.2014.08.004

82. Ma J, Ma P, Zhao CH, Xue X, Han HM, Liu CZ, et al. B7-H3 as a Promising Target for Cytotoxicity T Cell in Human Cancer Therapy. Oncotarget (2016) 7:29480-91. doi: 10.18632/oncotarget.8784

83. Watchorn E. Irradiated Ergosterol and Calcium-Free Diet: Effect on Calcium and Phosphorus Metabolism. Biochem J (1930) 24:1560-3. doi: 10.1042/ bj0241560

84. Davis ZB, Vallera DA, Miller JS, Felices M. Natural Killer Cells Unleashed: Checkpoint Receptor Blockade and BiKE/TriKE Utilization in NK-mediated Anti-Tumor Immunotherapy. Semin Immunol (2017) 31:64-75. doi: 10.1016/j.smim.2017.07.011

85. Kontos F, Kurokawa T, Vallera DA, Ferrone S, Ferrone CR. Il-15/B7-H3 TriKEs-Based Immunotherapy for Pancreatic Ductal Adenocarcinoma. J Am Coll Surgeons (2019) 229:S176-6. doi: 10.1016/j.jamcollsurg.2019.08.388

86. Vallera DA, Ferrone S, Kodal B, Hinderlie P, Bendzick L, Ettestad B, et al. Nk-Cell-Mediated Targeting of Various Solid Tumors Using a B7-H3 TriSpecific Killer Engager In Vitro and In Vivo. Cancers (2020) 12:2659. doi: 10.3390/cancers12092659

87. Adams JL, Smothers J, Srinivasan R, Hoos A. Big Opportunities for Small Molecules in Immuno-Oncology. Nat Rev Drug Discovery (2015) 14:603-22. doi: 10.1038/nrd4596

88. Vigdorovich V, Ramagopal UA, Lazar-Molnar E, Sylvestre E, Lee JS, Hofmeyer KA, et al. Structure and T Cell Inhibition Properties of B7 Family Member. B7H3 Struct (2013) 21:707-17. doi: 10.1016/j.str.2013.03.003

89. Chen S, Song Z, Zhang A. Small-Molecule Immuno-Oncology Therapy: Advances, Challenges and New Directions. Curr Top Med Chem (2019) 19:180-5. doi: 10.2174/1568026619666190308131805

90. Tang X, Wang YL, Huang JH, Zhang ZL, Liu FJ, Xu JG, et al. Administration of B7-H3 Targeted Chimeric Antigen Receptor-T Cells Induce Regression of Glioblastoma. Signal Transduction Targeted Ther (2021) 6:125. doi: 10.1038/ s41392-021-00505-7

91. Nehama D, Di Ianni N, Musio S, Du HW, Patane M, Polloc B, et al. B7-H3redirected Chimeric Antigen Receptor T Cells Target Glioblastoma and Neurospheres. Ebiomedicine (2019) 47:33-43. doi: 10.1016/j.ebiom. 2019.08.030

92. Theruvath J, Sotillo E, Mount CW, Graef CM, Delaidelli A, Heitzeneder S, et al. Locoregionally Administered B7-H3-Targeted Car T Cells for 
Treatment of Atypical Teratoid/Rhabdoid Tumors. Nat Med (2020) 26:712+. doi: 10.1038/s41591-020-0821-8

93. Yang MJ, Tang X, Zhang ZL, Gu L, Wei H, Zhao SS, et al. Tandem CAR-T Cells Targeting CD70 and B7-H3 Exhibit Potent Preclinical Activity Against Multiple Solid Tumors. Theranostics (2020) 10:7622-34. doi: 10.7150/ thno.43991

94. Tang X, Liu FJ, Liu ZY, Cao Y, Zhang ZL, Wang YL, et al. Bioactivity and Safety of B7-H3-targeted Chimeric Antigen Receptor T Cells Against Anaplastic Meningioma. Clin Trans Immunol (2020) 9:e1137. doi: 10.1002/cti2.1137

95. Yang S, Cao BH, Zhou GY, Zhu LP, Wang L, Zhang L, et al. Targeting B7-H3 Immune Checkpoint With Chimeric Antigen Receptor-Engineered Natural Killer Cells Exhibits Potent Cytotoxicity Against Non-Small Cell Lung Cancer. Front Pharmacol (2020) 11:1089. doi: 10.3389/fphar.2020.01089

96. Lei X, Ou Z, Yang Z, Zhong J, Zhu Y, Tian J, et al. A Pan-Histone Deacetylase Inhibitor Enhances the Antitumor Activity of B7-H3-Specific Car-T Cells in Solid Tumors. Clin Cancer Res (2021) 27:3757-71. doi: 10.1158/1078-0432.CCR-20-2487

97. Larkin J, Chiarion-Sileni V, Gonzalez R, Grob JJ, Cowey CL, Lao CD, et al. Combined Nivolumab and Ipilimumab or Monotherapy in Untreated Melanoma. New Engl J Med (2015) 373:23-34. doi: 10.1056/NEJMoa1504030

98. Xu Y, Xiao Y, Luo C, Liu QX, Wei AQ, Yang Y, et al. Blocking PD-1/PD-L1 by an ADCC Enhanced anti-B7-H3/PD-1 Fusion Protein Engages Immune Activation and Cytotoxicity. Int Immunopharmacol (2020) 84. doi: 10.1016/ j.intimp.2020.106584

99. Zhang W, Wang J, Wang YF, Dong F, Zhu MX, Wan WL, et al. B7-H3 Silencing by RNAi Inhibits Tumor Progression and Enhances Chemosensitivity in U937 Cells. Oncotargets Ther (2015) 8:1721-33. doi: 10.2147/OTT.S85272

100. Twyman-Saint Victor C, Rech AJ, Maity A, Rengan R, Pauken KE, Stelekati E, et al. Radiation and Dual Checkpoint Blockade Activate Non-Redundant Immune Mechanisms in Cancer. Nature (2015) 520:373-7. doi: 10.1038/ nature 14292
101. Ahmed M, Cheng M, Zhao Q, Goldgur Y, Cheal SM, Guo HF, et al. Humanized Affinity-Matured Monoclonal Antibody 8h9 Has Potent Antitumor Activity and Binds to FG Loop of Tumor Antigen B7-H3. J Biol Chem (2015) 290:30018-29. doi: 10.1074/jbc.M115.679852

102. Hegde PS, Chen DS. Top 10 Challenges in Cancer Immunotherapy. Immunity (2020) 52:17-35. doi: 10.1016/j.immuni.2019.12.011

103. White AA, Lee DN, Mazzola E, Kucukak S, Polhemus E, Jaklitsch MT, et al. Adjuvant Therapy Following Induction Therapy and Surgery Improves Survival in N2-Positive Non-Small Cell Lung Cancer. J Surg Oncol (2021) 123:579-86. doi: 10.1002/jso.26305

104. Minami Y, Nishida N, Kudo M. Radiofrequency Ablation of Liver Metastasis: Potential Impact on Immune Checkpoint Inhibitor Therapy. Eur Radiol (2019) 29:5045-51. doi: 10.1007/s00330-019-06189-6

105. Bialosky JE, Beneciuk JM, Bishop MD, Coronado RA, Penza CW, Simon CB, et al. Unraveling the Mechanisms of Manual Therapy: Modeling an Approach. J Orthop Sports Phys Ther (2018) 48:8-18. doi: 10.2519/ jospt.2018.7476

106. Lei KF, Ji WW, Goh A, Huang CH, Lee MY. Investigation of Uniform Sized Multicellular Spheroids Raised by Microwell Arrays After the Combined Treatment of Electric Field and Anti-Cancer Drug. BioMed Microdevices (2019) 21:94. doi: 10.1007/s10544-019-0442-5

Conflict of Interest: The authors declare that the research was conducted in the absence of any commercial or financial relationships that could be construed as a potential conflict of interest.

Copyright $\odot 2021$ Zhou and Jin. This is an open-access article distributed under the terms of the Creative Commons Attribution License (CC BY). The use, distribution or reproduction in other forums is permitted, provided the original author(s) and the copyright owner(s) are credited and that the original publication in this journal is cited, in accordance with accepted academic practice. No use, distribution or reproduction is permitted which does not comply with these terms. 